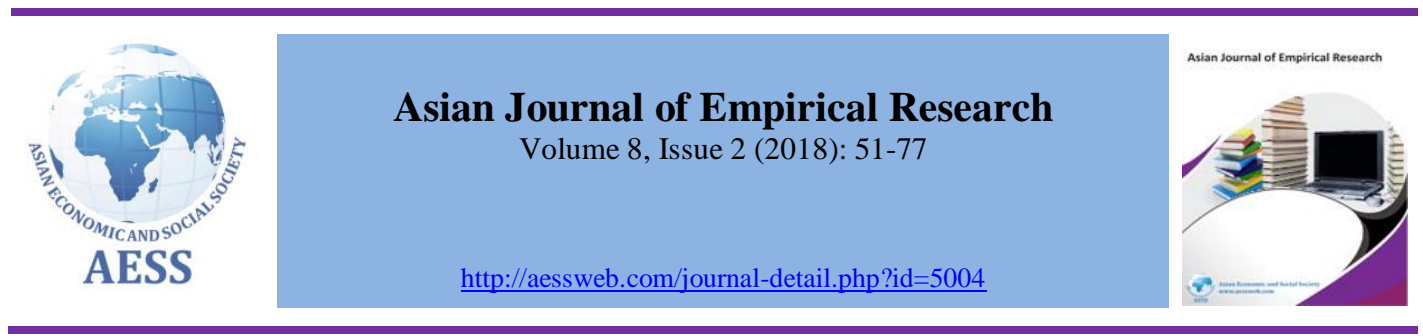

\title{
A paradox in consumer shopping behavior towards digital technologies in brick stores: an experimental approach
}

\author{
Vithyalega Shanmugarajah a $^{\text {a }}$ Sivapalan Achchuthan ${ }^{\text {b }}$, Balasingam Prahalathan ${ }^{c}$, \\ Natkunarajah Umakanth ${ }^{d}$ \\ ${ }^{\text {a }}$ Pantheon, Sorbonne University, France \\ ${ }^{\mathrm{b}}$ Lecturer in Commerce, University of Jaffna, Sri Lanka \\ ${ }^{\mathrm{c}}$ Senior Lecturer in Commerce, University of Jaffna, Sri Lanka \\ ${ }^{\mathrm{d}}$ Lecturer in Commerce, University of Jaffna, Sri Lanka \\ \achchu2009@gmail.com
}

\section{ARTICLE HISTORY:}

Received: $07-$ Dec-2017

Accepted: 06-Feb-2018

Online available: $21-\mathrm{Feb}-2018$

\section{Keywords:}

Brick and click stores,

Brand experience,

Digital Application,

Hedonic shopping value,

Utilitarian shopping value

\begin{abstract}
The main focus of this research is to analyze how digital in brick stores can affect the shopping experience. The study conveys new insights to the retailers to devise their digital strategy in the brick stores instead of blindly following a paradigm shift. As the previous studies of this research field has limitations in measuring the exact impact of digital due to variance of other factors, it was decided to use scenario based experiments. It was concluded that customers prefer to be served by service personnel than digital devices and only in the cases where the waiting time is more, customers prefer digital services. The more the utilitarian and hedonic values are given by a retailer, the more that shopping experience would be perceived as the best. Rather than following a digital paradigm, it is time for the retailers to take a pause and think how to differentiate themselves considering the customers' expectations to create a better shopping experience. To this end, a conceptual framework for shopping experience is created to summarize the results of this research study which can facilitate the retailers to create a wholesome shopping experience.
\end{abstract}

\section{Contribution/ Originality}

This study used an experimental approach and finds that digital alone does not impulse the consumer behavior. Hence, retailers should rethink innovatively to integrate the digital scenario in brick stores to facilitate the consumers to experience the brand satisfactorily. The study developed the conceptual frame work, which systematically incorporates the digital facilities in brick stores to create a wholesome shopping experience.

DOI: 10.18488/journal.1007/2018.7.2/1007.2.51.77

ISSN (P): 2306-983X, ISSN (E): 2224-4425

How to cite: Vithyalega Shanmugarajah, Sivapalan Achchuthan, Balasingam Prahalathan and Natkunarajah Umakanth (2018). A paradox in consumer shopping behavior towards digital technologies in brick stores: An experimental Approach. Asian Journal of Empirical Research, 8(2), 51-77. 


\section{INTRODUCTION}

Although e-commerce is growing rapidly, brick-and-mortar sales account for around $90 \%$ of the total retail sales in 2016 (eMarketer, 2016). Here brick store refers to a physical presence of a business usually owned and operated by a retailer but sometimes owned and operated by a manufacturer or by someone other than a retailer in which merchandise is sold primarily to ultimate consumers. There is also a trend that purely click stores are now opening brick stores for example Amazon Go and some click store brands open flagship stores with the intent of providing higher brand experience to create more loyal customers (eMarketer, 2016). There are some specific characteristics of brick stores which click stores do not possess and the brands should leverage them to create a unique shopping experience. Today many brands leverage the experiential marketing techniques for brand communication and the retail space has the potential to stage those experiential concepts driving more customer engagement and turn them as brand advocates (Kent et al., 2018). In other view, there is a growing concern in the retail industry due to the shift of its market share towards e-commerce retail. With the tremendous growth of internet and social media and in the fast-moving world, customers are becoming more time-sensitive and find more convenience in placing orders online. Hence, we are transforming towards fully digitalized stores. Also we cannot deny the services the e-commerce is providing in-terms of finding information about product, comparing products, getting advise from reviews and ratings from customers who have used the products, fast checkout process even with one click like in Amazon (Shetty, 2017; Goyal, 2017; Wang et al., 2016).

Interestingly, there is a "digital fever" among the retailers and "digitalizing the in-stores" has a broader meaning and it includes many concepts and technologies such as sending customized offers when customers entering the stores, "digital shopping cart" meaning placing orders in a digital screen to include the products not in-stock, a social media wall to communicate on online social media of the brand, "zero-checkout" meaning no waiting time for checkout where customers can pick up products and pay through an app (Hagberg et al., 2016). Further than, there is a new trend in retail stores which aim to attract young digital customers by creating a fun and engaging experience in their stores through digital technologies which cannot be achieved through other marketing channel. Fascinatingly, in other viewpoint, many online brands which are successful in online sales also start opening their brick stores and some brands open flagship stores without product sales with the aim of enhancing brand experience. Also many researches evolved in parallel which highlighted the need for looking into different dimensions of shopping experience and leveraging the capabilities retail stores have to create a unique experience to customers and make it as a competitive advantage (Kent et al., 2018). In this context, in store - digitalization techniques might be the potential strategy to enrich the customer shopping experiences in the brick stores. Because, in store - digitalization techniques facilitate the customers to experience the benefits of both brick and click stores in one platform. There are several studies have attempted to identify the impact of e- commerce platform on the consumer shopping experiences albeit, an exploratory investigation, the main focus of this research is to analyze the impact of digital in the brick store shopping experience. To this end, the in-store digital experience does not mean the omni-channel strategy but any digital technology or component installed in the brick store in order for customers to interact with it.

\section{THEORETICAL FRAMEWORK}

There are many research works published and many theoretical concepts evolved around the retail industry in the field of psychology, marketing, retailing and consumer behavior (Grewal et al., 2017). The focus of this research is to understand what shopping experience and brand experience mean and to explore the impact digital technologies can create in brick-stores' shopping experience and brand experience. The literature reviewed and the concepts related to this study are detailed below:

\subsection{Customer experience}

The customer experience construct is holistic in nature and involves the customer's cognitive, affective, emotional, social and physical responses to the retailer (Grewal et al., 2009; Puccinelli et 
al., 2009). This experience is created not only by those elements which the retailer can control (e.g., service interface, retail atmosphere, assortment, price), but also by elements that are outside of the retailer's control (e.g., influence of others, purpose of shopping). The customer experience encompasses the total experience, including the search, purchase, consumption, and after-sale phases of the experience, and may involve multiple retail channels (Verhoef et al., 2009).

\subsection{Hedonic and utilitarian shopping values}

In general there are two types of values or rewards perceived for any human behaviour: a utilitarian outcome resulting from some type of conscious pursuit of an intended consequence and an outcome related to spontaneous hedonic responses (Ozturk et al., 2016). These two types of value are useful in describing shopping's rewards and a shopping experiences can indeed produce both utilitarian and hedonic value (Babin et al., 1994; Ozturk et al., 2016; Ozkara et al., 2017).

In contrast to the traditional marketing, which focused on functional or utilitarian factors of the consumption, researchers proved that hedonic factors are also important in enhancing the customer experience (Ozturk et al., 2016; Ozkara et al., 2017). Schmitt (1999) presented five types of experiences the marketers can create namely Sense, Feel, Think, Act and Relate. According to Schmitt (1999), Sense marketing focuses on creating sensory experiences that appeal to consumers' senses (sight, sound, touch, taste, and smell), Feel marketing appeals to customers' inner feelings and emotions, ranging from mildly positive moods linked to a brand (e.g., for a non-involving, nondurable grocery brand or service or industrial product) to strong emotions of joy and pride (e.g., for a consumer durable, technology, or social marketing campaign), Think marketing focus on the intellectuals to deliver cognitive, problem-solving experiences that engages them creatively, Act marketing focus on enriching customers' lives and target on physical experiences, and showing alternate lifestyles and the Relate marketing creates experiences which expand beyond the individual's personal feelings and appeal to the customers' desires of being part of a broader social system (Schmitt, 2011). These researches prove that customer experience has got these different dimensions: sensory, affective, cognitive, behavioral and social. It was highlighted that wine tasting stations, mouth-watering aromas waft out of the bakery and rotisserie chicken areas, demonstration kitchen where chefs prepare and serve items to promote cooking methods and recipes using H-E-B products are differentiating factors transforming the grocery shopping from a monotonous, mundane activity focused on meeting needs into an exciting and inspiring experience filled with discovery and entertainment.

\subsection{Brand experience}

Brakus et al. (2009) did an extensive research on brand experience and discussed in his research paper that experiences occur in different stages and grouped into these three categories: product experience occurs when consumers search for products, interact with product either directly or indirectly through advertisements etc., shopping and service experience occurs when a consumers shops for the product and interact with store's physical environment, sales persons in the store etc., and consumption experience occurs when consumers consume and use the products. Brand experiences are actual sensations, feelings, cognitions, and behavioral responses which may result in emotional bonds (Choi et al., 2017). Brand experience is related but conceptually different from other brand constructs such as brand attitude, brand involvement, brand attachment, customer delight and brand personality (Choi et al., 2017; Saari et al., 2017). Brand experience affects consumer satisfaction and loyalty directly and indirectly through brand personality associations (Brakus et al., 2009). Brakus et al. (2009) developed a scale that can measure the strength with which a brand evokes each of these experience dimensions: sensory, affective, intellectual, behavioral, or social experience. It was also proved that brand experience has a behavioral impact; it affects consumer satisfaction and loyalty directly and indirectly through brand personality (Brakus et al., 2009; Choi et al., 2017; Saari et al., 2017).

\subsection{In-store experience}

Retail or physical store is not only a distribution channel to sell the products but is also being used by brands as communication tool in marketing and brands strive hard to create memorable experiences in-stores (Bullard, 2017; Terblanche, 2018 and Kent et al., 2018). Thus if a retail brand can create 
such memorable experience, it is proven that it not only engages the existing customers but also create new loyal customers. This marketing strategy doesn't need to fit only luxury brands, but can also be adopted by any retail store. Retailing researchers highlight the importance of creating a social environment that leads to the co-creation of experience (Kent et al., 2018). Borghini et al. (2009) studied the American Girl Place a culturally rich and highly successful retail environment and described how the ideology of the brand manifested powerfully through a variety of different and distinct areas within the store. "In particular, the brand is enacted through the telling and retelling of the American Girl stories, many of which are learned, practiced and enjoyed within particular areas of the store, such as the Café, the Library, or the Theater. An appropriate retail strategy is to stimulate and facilitate this brand enactment. By identifying the ideology of the store is, and how it can be communicated, it can be built into consumer-to-consumer interaction". (Borghini et al., 2009; Kent et al., 2018).

Flagships and brand stores can contribute to building brands and the relationship between store image, brand experience, brand attitude, brand attachment and brand equity was researched by (Dolbec and Chebat, 2013). As flagships can create strong and powerful brand experience, they have a stronger impact on brand attitude, brand attachment and brand equity compared to brand stores. Retail marketers can leverage this to offer increased in-store brand experiences by appealing to consumers' emotions, senses, behaviors, and cognition (Dolbec and Chebat, 2013). Dolbec and Chebat (2013) proved that positive store image increases the brand experience and it impacts three brand constructs: brand attitude, brand attachment and brand equity. Store type moderates the relationship between store image and brand experience, and the authors concluded that the flagship increases brand experience in comparison to the brand store. The combination of a well-designed shopping experience, welltrained sales personnel, possibility for immersion and co-creation of the spectacle increases the impact of the store image on consumers' in-store brand experience. From the brand experience and retail experience researches it is evident that the retailers can enhance the in-store brand experience by appealing to customers' senses, physically, emotionally, and intellectually (Brakus et al., 2009; Choi et al., 2017; Saari et al., 2017; Kent et al., 2018).

\subsection{Digital retail experience}

Though the brands are adopting several strategies to create a better shopping experience, it is now a trend or need for physical stores to incorporate digital in the shopping experience with the evolution of The Internet of Things (IoT) (Kent et al., 2018). IoT refers to the ever-growing network of physical objects that feature an IP address for internet connectivity, and the communication that occurs between these objects and other Internet-enabled devices and systems (Parise et al., 2016; Reydet and Carsana, 2017). This IoT is transforming the retail industry not only in the supply chain but also plays a key role in enhancing customer experience in their shopping journey by filling the gap between click and brick stores. It triggers the question what concepts and experience of click stores can be incorporated by physical stores (Parise et al., 2016; Reydet and Carsana, 2017; Kent et al., 2018). Omni-channel retail is a requirement today where the customers can place order in a website, try or collect or return it in a retail store. Creating a unified customer data is required in order for customers to have a seamless customer experience as customers can be identified online and in-store and customers can manage all orders in one place and the business can have better data about the customer and can target customers in a better way (Parise et al., 2016; Reydet and Carsana, 2017; Kent et al., 2018). This omni-channel strategy is not the focus of this research as that is broader but the focus is only on brick store shopping experience and to understand how the digital technologies installed in the stores affect the customers experience in brick stores.

\section{METHODOLOGY}

\section{Study 1: Observation of shopping behavior}

As this is an exploratory study, inductive research method is applied. In a research for developing shopper segments (Sinha and Uniyal, 2005) discussed in detail about how to study the shopping behaviour of consumers in the methodology of their research and highlighted the validity of an 
approach to directly observe shoppers while they perform their shopping activity. It was stated that this observation method is useful in these cases: "uncover unconscious consumer actions, small product annoyances that might otherwise go unnoticed, or potential unfulfilled needs of emerging markets" (Wimmer and Stiles, 2001).

The objective of this study was to identify how consumers respond to the digital technologies in brick stores. It was decided to follow these steps in this study: The authors planned to visit at least 10 stores including digital and non-digital stores, to enter the store like a shopper and to observe the consumer behaviours and their responses to digital technologies in case the store has, take field notes of the observation. The field notes are analysed using Grounded Theory Approach which is a systematic methodology in the social sciences involving the construction of theory through the analysis of data (Johnson and Sohi, 2016; Charmaz, 1995). The details of the stores visited and key field notes of the observational study used for the analysis are attached in the appendices (Annex 1). In order to make the comparison easier without any bias towards the brand, the observation of the stores from the same retail brand Sephora in Paris is described here. There are two Sephora stores which does not have any digital services in the brick stores were visited and are referred to as "non-digital store". Another store Sephora Flash which has some digital services was visited and will be referred as "digital-store".

\section{Study 2: Qualitative data analysis}

As the observational study may lead to subjective analysis of the author, it was decided to collect data from the customers to understand their perceptions about the shopping experience to identify the factors behind the observed behavioural responses of customers in brick stores.

\subsection{Primary data collection}

A questionnaire is prepared to collect the primary data to identify what is perceived as best and worst shopping experience to find out the correlating factors behind the high experiential brand store. As the best brand experience or worst brand experience that is in memory would affect the customer's loyalty towards that brand, the responses for this questionnaire were not collected in-store but off the store. It had these 2 open questions:

1. Describe the best retail shopping experience you had recently in a physical store?

2. Describe the worst retail shopping experience you had recently in a physical store?

The responses collected from 8 participants are analyzed. This qualitative study helped the author to understand the customers' perceptions about good or bad shopping experience.

\subsection{Secondary data analysis}

In order to get more insights on customer experience of the stores the author visited, the comments shared on the Google reviews are analyzed. The google sample reviews analyzed are listed here and the comments in French are translated to English.

\section{Study 3: Shopping experience scale}

In addition to the above two studies, it is necessary to ground the further study, which should examine the main theme of this research work as "click stores experience in a brick store". In this context, author(s) mainly frame the study three to examine the brand experience and the shopping experience simultaneously in brick stores with digital applications. Moreover, the authors have framed a questionnaire with 2 sections using 7-point Likert scale to measure the brand experience and the shopping experience. To measure the brand experience, the scale proposed by Brakus et al. (2009) is used and to measure the shopping experience, a scale is created by the author with the qualitative study done in the previous step.

\section{Study 4: Experimental vignette methodology}

This research also intends to identify what extent digital can enhance the brand experience as many brand follow this trend in their branded store or flagship store. Though the observational study gives 
the insights and leads to the hypothesis that digital is not enhancing brand experience, due to the subjective nature of the analysis, the author decided to conduct a quantitative survey from customers to understand their perceptions. As this hypothesis can be tested better only if data is collected from the same brand, from the same customer and with only digital variable altered, there is a limitation in collecting such data. To validate this hypothesis, a quasi-experimental method EVM (Experimental Vignette Methodology) is followed. EVM studies consist of presenting participants with carefully constructed and realistic scenarios to assess dependent variables including intentions, attitudes, and behaviors, thereby enhancing experimental realism and also allowing researchers to manipulate and control independent variables as analyzed by Aguinis and Bradley (2014) The author framed two scenarios by manipulating the digital variable in the in-store shopping experience as shown below. It was assumed in the scenarios that utilitarian factors are satisfied.

\section{FINDINGS}

\section{Study 1: Observation of shopping behavior}

In nutshell, The digital store has these features: the customers can use the "digital cart" feature which is a card to be used when choosing products in the digital screen available to add products not in-stock in the store to the cart and pay together, take selfies and share by email, collect samples through digital screen after checkout and small digital screens showing product information. To describe briefly: nondigital store are larger, more customers, sales persons offering assistance, customers were seen as more enthusiastic when trying the products and in the make-up stations and more variety of products.

The inference from this study is that most of the consumers prefer non-digital touch and feel experience than digital experience through touch screens. Customers prefer to get advice from sales personnel directly and to try and explore the products by themselves taking their time. The digital technologies created for the purpose of fun with the intent of engaging customers are not really gaining attention of the consumers. Digital technologies which replicate the services available online in the ecommerce channel for example click \& collect are not mostly used by customers in the brick stores. The digital self-service technology is used in a stage and a place where there is more waiting time for customers and there is no need to touch and feel the products, for example at the checkout counter if there is a big queue, at the order placement in a fast-food chain like McDonad's.

\section{Study 2: Qualitative data analysis}

Researchers in this work framed the qualitative approach to find out factors behind the observed behavioral responses of customers in brick stores. Further, Researchers used both primary and secondary data collection methods to support the study Two.

\subsection{Qualitative fats (Primary data)}

With the two questions (Best and worst retail shopping experiences in Brick Stores), Researchers construed the study frame to examine the factors associated with the observed behavioral responses of customers in brick stores. The narrative facts of eight respondents have been documented below. This study approach was carried by researchers in the month of January, February and March of year 2017.

Respondent one [Age: 24 and Sex: Female)

Best retail shopping experience

"To be fully honest, I can't tell you the best shopping experience. Considering that physical store are anxiety-provoking for me, I tried as much as possible to avoid them. Besides, I recently ordered books on amazone and it was a simple, quick and efficient interaction with the brand. I received my books in 3 days and I didnt have to take my car to go to the store. I am waiting for the next Amazon Shop (just like the physical store in Seattle) !!"

Worst retail shopping experience 
"I went in E.Leclerc Espace Culturel to buy some books. It was a big physical store with a lot of choice (normally!). I needed 3 books: „The great escape“ by Angus Deaton (in english), „La médiocratie "d'Alain Deneault and ,Televisions" de Bruno Patino. I went to the desk to ask for those books. The seller looked on his computer and tell me than he did'nt have the two first. Then He told me ,, but I get the last one entitled „, Televisions “. I told him „, Well great! Lets go to find him !“.... We never found it... I was looking during almost half an hour and when I left the shop, I did'nt have any of my desirable books! Those two experiences are linked because after that I ordered those books on Amazon."

Respondent Two [Age: 47 and Sex: Male]

Best retail shopping experience

"I went to a "Bose shop" because $i$ was looking for good speakers. Better than a shop, it was a "show room" where we can listen music in the perfect environment. I tried several products "Home cinema 5.1", Speaker for the bathroom, for the living room... The vendor was really likeable and had the patience to accompany me and my wife. He was ready to meet our demand even if we didn't really have a clear idea of the product we were looking for. We were just attracted by the brand itself because we love music. After having listened several products, we were completely amazed by the quality of Bose but we didn't buy anything at this time. The vendor said "Take your time, we'll be pleased to receive again; here is my business card" One week later, we came back to him and we bought a beautiful speaker for $800 €$ with a big smile on our face. We plan to buy the home cinema next time because we are really convinced by the quality of sound of this brand."

Worst retail shopping experience

"This week, we went to a clothing store, attracted by the price (French soldes) of a "Jean". We enter the store and saw the vendor talking with a customer. They were alone in the store. The vendor (she) didn't look at us. We said "Hello" and no response from her... We looked at the "Jean" and finally we were not interested by the product. No help from the vendor and no curiosity.... So, we left the store and said "bye bye" to the vendor. No response neither... Very very strange behavior. They don't need money in this shop!"

Respondent Three [Age: 28 and Sex: Female]

Best retail shopping experience

"It was at Sephora where I was buying Christmas gifts for my family and the lady working at the store was very patient to let me try and advise me on all the new perfumes thats suits my taste. She even asked several questions to try to understand what I am looking for. In addition, she even advised me on the discounts I could get on my purchases so I would be able to save money."

Worst retail shopping experience

"It was at a pharmacy where I was asking for a certain kind of medicine and the personnel wasn't helpful at all. He was a bit rude as all he said was we don't have this and looked at me in a way that he was waiting for me to leave. He didn't try to ask me what is it for or what else he could provide as an alternative. Impatient and hostile attitude while the place was empty, not too many customers."

Respondent Four [Age: 34 and Sex: Female]

Best retail shopping experience

"I tend to do all my shopping online, so I am not the most qualified to reply to these questions. I tend to get annoyed really quickly by doing shopping, but one store does not have that effect on me and that is Nature et découverte. I think that it is because there is a sort of peace when you wander around in the store, there are separate space for every type of items they are selling, which makes it easy to 
find what you are looking for. You can test products, and you can easily see how you can use them. they are staged within the store."

Worst retail shopping experience

"What makes retail shopping experience bad in a general sense is: Not enough or too much help from the vendors; Not being able to find your way to the items you are looking for; Empty shelves, meaning you went to the store for something specific and you couldn't find it And in a more general sense, I think staging is quite important. For instance Abercrombie has a great retail experience, but I myself do not feel at ease because the space is quite dark, loud music and it gets crowded very quickly.... I must be too old for this."

Respondent Five [Age: 25 and Sex: Female]

Best retail shopping experience

"I went in a small store in Paris (near beaubourg), when we walked in the store the sellers noticed us and said hello, if we had questions or needed informations they were here for us. The products were very well presented, they had a lot of diversity in their products (accessories, decoration, plants, jewelries.....). It was a very "cozy" atmosphere and we didn't felt any stress or emergency of any discomfort."

Worst retail shopping experience

"I went in a concept store which was open for Christmas (in Paris near the Bhv) : the place was very nice, it looked like a little house, but it was very crowded, the customers were rude (everyone walked on everyone etc.) and very pretentious. There were many corners with the creators of every brand, but they didn't looked very comfortable"

Respondent Six [Age: 31 and Sex: Female]

Best retail shopping experience

"Shopping in Sephora gives me a nice shopping experience, see and test the products and get professional service that is tailored to my needs as well as a quick checkout process."

Worst retail shopping experience

"Waiting on a very long line to pay form my goods in especially in the supermarkets on weekends or feeling confused in a shop without any advice from a slaes person."

Respondent Seven [Age: 24 and Sex: Female]

Best retail shopping experience

"When I am going in store, I generally know what I want and I don't want to spend so much time because there is always too much people. But when I am in a cosmetics store, everything is different because I am here to try and test new products. And most of the time seller are nice. So let's take the example of Lush Store. There are a lot of products that I don't fully understand and each time the seller are here to explain me everything let me test each product I want. They always know how to make you special and understood. There is no judgment, just advices, listening and customer experience."

Worst retail shopping experience

"A thing that I hate in a clothing store (like H\&M, Mango, ZARA, big ones), is that every time that you are reaching a seller they are talking to you as if you were nothing. Only few of them or nice and 
take time to advice you. Two weeks ago I went in a Mango store, I was trying to find my size for a dress. So I ask a seller if she knew if there was my size. She told me "I don't know, look around you ", I ask her what was her advice if I really wanted this dress (because I know she supposed to refer me to their web store) and she told me " to find and another one are to lose some weight "... Not really nice and unexpected. So I told her that I needed to speak with her director, she called her and just after I left. I didn't wanted to waste more time I just wanted to make sure she felt bad about want she said and maybe realized how rude she was."

Respondent Eight [Age: 50 and Sex: Female]

Best retail shopping experience

"The best retail shopping experience $i$ had recently was in IKEA when $i$ inquired about a kitchen set package. My French wasn't good but still the IKEA staff was very accommodating and spoke to me in French, but a bit slowly to adjust to my level of French. I was led to a dedicated customer sales area with tables (with computers on them) and chairs where the IKEA sales staff discussed with me some options on the kitchen set I wanted. The electronic model of the kitchen was done by the IKEA staff very quickly, in less than 15 minutes, with all the itemized cost, as well as information on available financing options and delivery details and cost. The staff greeted me Bonjour with a smile and also wished me a good day with a smile at the end of the discussion. What was also great was that the staff registered me in the system so that I can alter the kitchen model if I wanted to, since I told her I would discuss the quote with someone before deciding. What was also nice in the whole experience was the IKEA."

Worst retail shopping experience

"The worst retail shopping experience I had recently was in Orange Telecom boutique. I went to an outlet near Place D'Italie to inquire about a new phone and options on monthly subscriptions. The queue was very long and the small store was crowded, both by potential buyers of new phone/subscriptions and by existing customers who are there for some complaints. After queueing for so long, around 30 minutes, I finally got to talk to an Orange staff, who, when she learned that my French is not very good, started talking even faster, leaving me blank-faced because I couldn't understand anything. The staff didn't look friendly and I felt like he just wanted to end the conversation quickly and get rid of me, so I just said, Merci beaucoup, au revoir!

In short, this qualitative study helped the author to understand the customers' perceptions about good or bad shopping experience. In those responses, mostly the utilitarian factors were mentioned by the respondents and the most repeated attributes which were perceived as best shopping experience are: good assistance or advice from sales persons, variety of products, fast checkout process with less waiting time, less crowded space, no rush to choose or try the products. There was one respondent who mentioned about the role of digital when explaining about the shopping experience in IKEA: "The electronic model of the kitchen was done by the IKEA staff very quickly, in less than 15 minutes, with all the itemized cost, as well as information on available.financing options and delivery details and cost". This gives an insight that digital accompanies the employees to explain the choices and help the customers to make their purchase decision. The respondent also mentioned: "The staff registered me in their system so that I can alter the kitchen model if I wanted to, since I told her I would discuss the quote with someone before deciding". Having a unified channel and providing services across all customers seemed to increase the customer engagement.

\subsection{Qualitative fats (Secondary Data)}

In order to get more insights on customer experience of the stores the author visited, the comments shared on the Google reviews are analyzed. The google sample reviews on or after 2015 analyzed are listed here and the comments in French are translated to English. 


\section{Sephora (non-digital store)}

\section{Comments with rating > 3: (Favorable Response)}

"Amazing product selection and many helpful staff wandering around, superb service! Got asked if I needed help twice by the assistants, it is service with a smile. Got two small samples for my little mascara purchase. Thank you!"

"Superb service! Got asked if I needed help twice by the assistants, it is service with a smile. Got two small samples for my little mascara purchase. Thank you!"

"As the flagship store is great if you love makeup. I myself as a man who's not really into makeup would probably give it a pass, but my girlfriend highly recommends it. Countless brands for a medium to fairly expensive but respectable and solid price."

\section{Comments with rating < 3: (Worst Responses)}

"I will never return to this Sephora again! Salespeople do not do their job that is to inform the customer. A minimum of accompaniment in the shopping route may be required when the shop is virtually empty." "Too much people" "Twice I come the shopkeepers do not know each other and are not pleasant." "The reception, very bad, very cold. Staff not available for guests and unfriendly."

"Rich collection of french and Italian perfumes. But overpriced products and aggressive salespersons. It is more about getting money out of incoming costumer than customer satisfaction and making them return.

\section{Sephora Flash (digital-store)}

\section{Comments with rating > 3: (Favorable Response)}

"Helpful and efficient"

"Technology blended with beauty, top advisers, I buy my eyes closed, I like it all the products and the saleswoman are very nice :)"

\section{Comments with rating < 3: (Worst Responses)}

"staff averagely welcoming and always line up at the checkouts when you know what you want it is not necessarily faster"

"Ok" "Smaller than other Sephora's shops, not so great choice"

\section{Nike store (digital-store)}

\section{Comments with rating > 3: (Favorable Response)}

"Fantastic, they ran out of our size, but the gentleman figured out the conversion of the female sizes and found us what we were looking for despite all odds. Saved us as one of our party came to Paris with a bad choice of footwear."

"Very big range. Busy but great staff."

"Helpful service. We bought shoes here in late 2015, and the staff put us on a jogging machine that evaluated our running style."

\section{Comments with rating < 3: (Worst Responses)}

"Very bad service. You spend a lot of time waiting for sizes and the sales advisers are not friendly."

"This store is very expensive. Like, really expensive. $150 \$$ for some pants expensive."

"The staff not helpful and they rude"

In nutshell, it is found that good customer service, friendly sales personnel providing the needed assistance, availability of product variety, less crowded retail space are perceived as good experience. From the limited search of comments done by the author, the role of digital in the customers shopping experience was not mentioned. From this analysis, the secondary data almost match with the results of observational study and the qualitative data collected. 


\section{The findings of Study 3: Shopping experience scale}

With the analysis done so far, it is clear that customers do not want to wait except when trying out the products where they would like to take time in order to make decisions. So for any customer, it is important to pass quickly between the other stages of the shopping. As the click stores experience is perceived as fast, time-saving and efficient, the skeleton of an e-commerce store is used to analyze how it can be mapped to brick stores shopping journey.

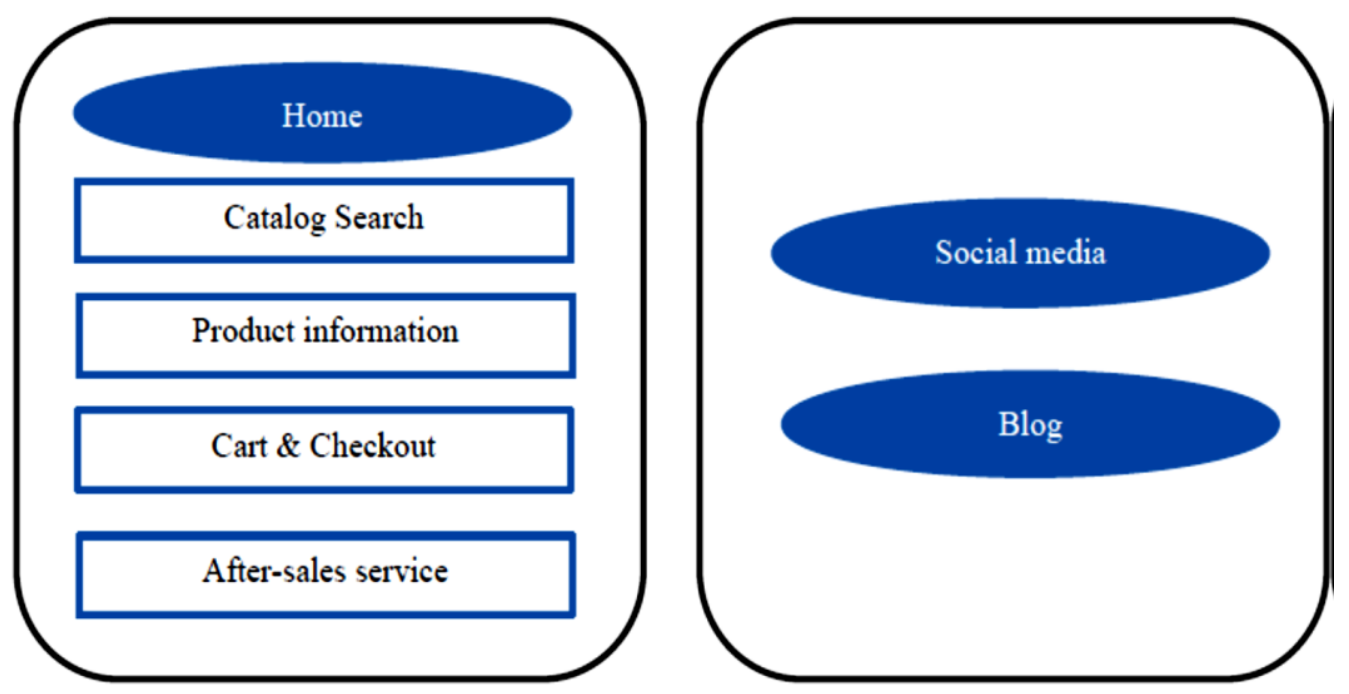

Figure 1: E-commerce shopping experience components

In the above figure, the items in rectangle are utilitarian factors and items in oval are hedonic factors. The corresponding mapping of each component of click stores experience in a brick store is explained below:

Home: The retail store environment, its ambience plays a major role in making customers to enter the store.

Catalog search: The retail store setting for example assortment, signage are important for customers to identify their products. If required, the sales personnel should assist the customer to find their products.

Product information: Though the product information is available on the product or the customer knows about it in advance, when required the sales personnel advice is required. Product testing plays a major role here in brick stores.

Cart \& Checkout: The checkout step needs to be faster and enabling checkout through mobile payment devices used by the checkout assistants is perceived as better service.

After-sales service: After sales service includes service to return the products or repair the products. Service personnel need to facilitate the customers in this stage and it is also an important factor in rating a shopping experience like all the other components.

In all the above stages which are perceived as utilitarian values of shopping experience, service personnel play a major role in creating or adding hedonic values on top of that The major hedonic concepts of e-commerce and its corresponding mapping are given below:

Social media: The community management concepts need to be incorporated in the brick stores like make-up courses in Sephora, running-club in Nike. 
Blog: The retailer brands need to communicate about their brand and tell their brand stories to customers in stores.

\subsection{Brand experience scale (Hedonic)}

The following brand experience scale proposed by Brakus et al. (2009) comprising 12 questions which measures the brand experience across five dimensions namely sensory, affective, intellectual, behavioral and social is used:

[Twelve questions are : This brand makes a strong impression on my visual sense or other senses; I find this brand interesting in a sensory way; This brand does not appeal to my senses ; This brand induces feelings and sentiments; I do not have strong emotions for this brand; This brand is an emotional brand; I engage in physical actions and behaviors when I use this brand; This brand results in bodily experiences. ; This brand is not action oriented; I engage in a lot of thinking when I encounter this brand; This brand does not make me think; This brand stimulates my curiosity and problem solving ]

\subsection{Shopping experience scale (Utilitarian)}

The following questions considering the factors identified as important in a shopping experience from the above two studies (Study 1 and 2) is used:

[Six questions are: I can easily find my product; I can find required information about a product; I can compare products easily before making the purchase; I don't have to wait more time to complete my order; I can easily manage my returns; I get relevant tips before purchasing a product]

This questionnaire is submitted to 24 respondents of different profile living across the world and the responses are attached in the appendices (Annex 2). It is evident from the results as shown in the graph in Figure 2 below that even if some brands are not strongly experiential, due to the fact that utilitarian factors of a shopping experience is fulfilled, the shopping experience is perceived as the best by the customers.

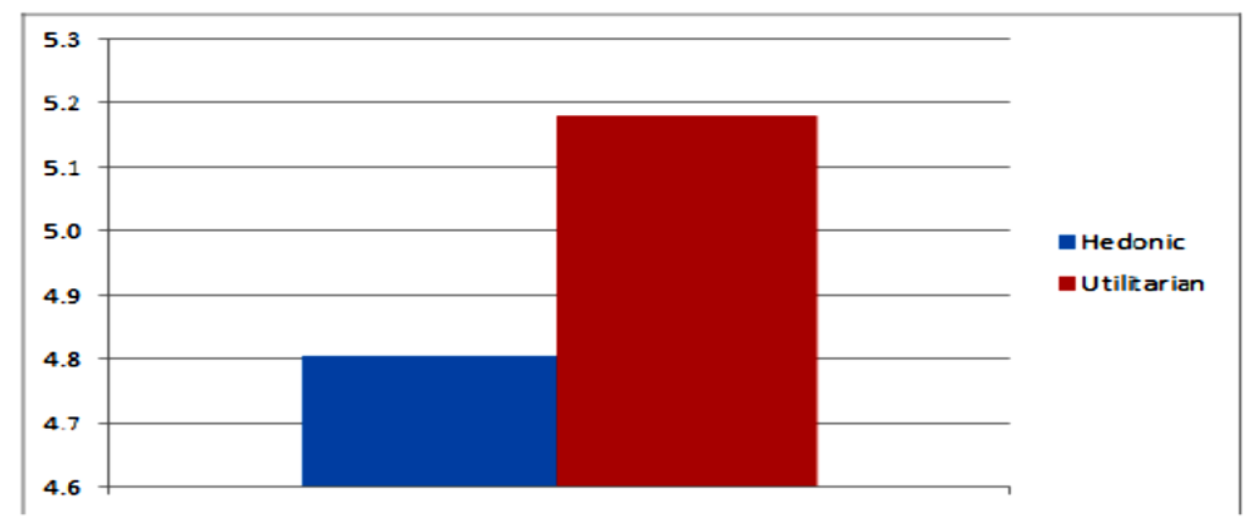

Figure 2: Strength of hedonic and utilitarian factors in the best shopping experience

Further, the best shopping factor is mostly affected by the product searching and getting relevant advice from the sales personnel though ratings for product comparison. Here digital technologies can help the sales assistants to provide better demonstration about the product, comparison information and to enable fast checkout. Moreover, based on the analysis in line with both brand and shopping experiences (Annex 2), sensory and affective experiences are stronger compared to behavioral and intellectual experiences. This highlights the fact that many retail brands perceived as providing best shopping experience from the participants do not concentrate on the different dimensions of brand experience. They concentrate on the utilitarian factors due to their strategic position as this is the case 
for many super market or department store chains but sensory and affective experiences are created through the store environment and friendly service.

This study makes it clear that it is required to have the utilitarian factors to get satisfied in order to create the best shopping experience. Although the stores mentioned by the respondents are not digital, the qualitative data collected in previous studies (Study $1 \& 2$ ) show that digital technologies can enhance the shopping experience if it accelerates and facilitates the shopping journey of the customers with the assistance of sales personnel except the case of the product trial where customers prefer to spend more time with or without any assistance from sales person rather than digital technologies. More retailers are still competing on the utilitarian factors and it is time for the retailers to think about creating hedonic values to create a wholesome shopping experience.

\section{The findings of the Study 4: Experimental vignette methodology}

The researchers designed two scenarios to conduct the experimental work. Two scenarios are explained here in detailed.

\section{Scenario 1 (Non-digital store)}

"You enter a branded shoe retail store and a sales person greets you at the entrance and you are glancing through the available products, you cannot find your product and you ask for help to a sales person nearby and explain him/her about the product you are looking for and the sales person asks you for more information on its specification like colour, price, style etc., and he shows you a list of products matching close to your specification. He shares his review as well as the review of other customers about the matching products and let you to take your time in trying them and to make your choice. You choose a product which you like and go to the cash counter, pay your bill and collect the product and leave the store. You get a pamphlet stating the dates of weekly community programs like games, style guide for the brand, seminars on personal development, marathon etc., organized in the store for the month and you are instructed that you can opt-in for it by registering your loyalty id. In the first page of the pamphlet, you can see the photos and names of the prize winners of the last month community programs and their comments."

\section{Scenario 2 (Digital store)}

You enter a branded shoe retail store and there is a big digital wall that lists the available products in different categories, you can search for your product through the search and it shows you a list of products matching your specification. You can also compare each product with others and read the reviews and ratings of each product shared by the online customers. There is a virtual mirror in the screen where you can try multiple products virtually. You choose a product which you like and pay for it with your mobile app or with the payment kiosk and take the product. There are some digital touch screens which displays the communication about the brand in social media, its blog and you can also browse through and opt-in for the different online community programs like games, style guide for the brand and personal development courses etc., It also displays the comments shared by the prize winners of the community programs organized by the brand in social media last month.

The above 2 scenarios were submitted to 21 participants along with the brand experience scale for each and the results as shown in Figure 3 below show that non-digital scenario has more impact on brand experience than digital stores and most of the customers prefer the non-digital stores over digital-stores. The responses are attached in appendices (Annex 3). 


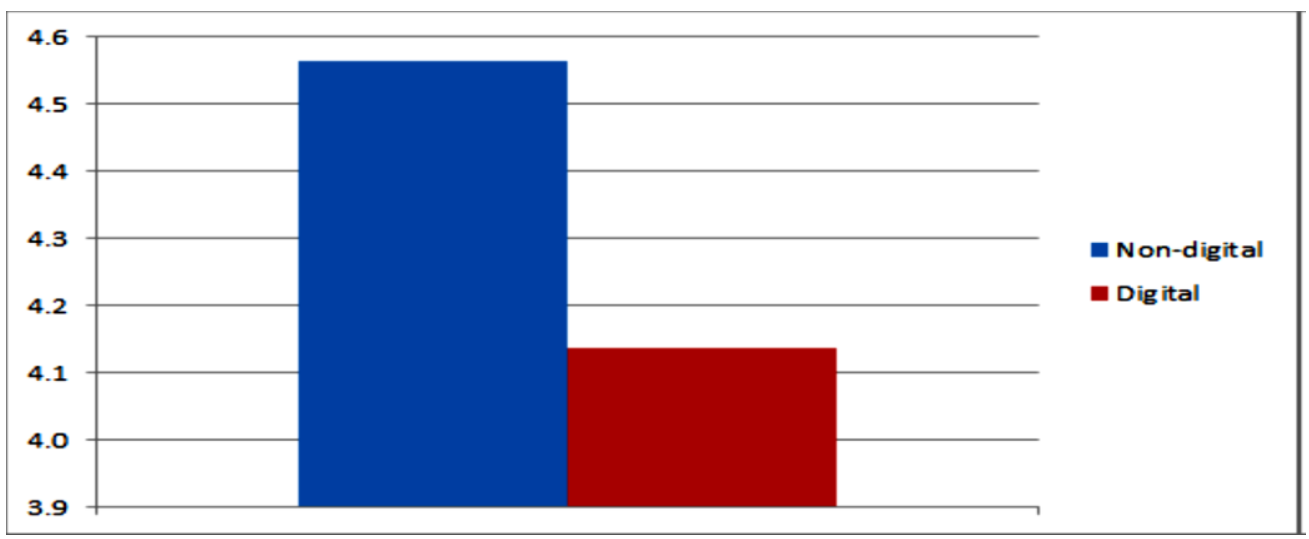

Figure 3: Strength of brand experience in digital and non-digital scenarios

\section{DISCUSSION}

\subsection{Impact of utilitarian factors on shopping experience}

The qualitative data and the quantitative data collected prove that customers get satisfied when the utilitarian factors are fulfilled. The utilitarian scale better measures the shopping experience perceived as best by the consumers than the brand experience scale which measures the different dimensions of brand experience. Facilitating the customers across all the touch points from the awareness to the purchase stage and also including the after-sales services like return management will create a positive impact on the shopping experience.

\subsection{Impact of hedonic factors on shopping experience}

The qualitative data and the data from the observational study of in-store consumer behavior show that the service personnel and the ambience of the store play a major role in this customer journey especially in stores. Treating customers in a friendly way and offering better service quality seem to create a positive impact on the shopping experience and the brand experience. There are other brand experience dimensions like behavioral and intellectual which are not addressed by many retail brands and potential area where retailers can search their competitive advantage.

\subsection{Impact of digital on shopping experience}

As there is a limitation in the quantitative data on the numbers and group of respondents representing luxury and economy customers, digital and non-digital customers, the scenario based testing, the qualitative data from the customers and the data collected from the field work done by the authors by visiting and observing the consumer behaviors in the stores prove that there is a paradox in what some brands are doing by installing digital touch screens in their stores in the name of creating digital experience because customers expect friendly service in the brick stores and expect to be served by sales personnel than digital screens. Customers prefer the experience created by non-digital stores than digital stores which makes sense with the fact that customers can use online channels like internet and social media and when they come to stores, it is to have one-to-one contact with sales person to get their advice and to touch and try the products. Though when a brand make its store digitalized, it becomes a hype in the social media, there is no evidence that it actually enhanced the brand experience and is an important question to ask about its ROI before formulating the in-store digital strategy and investing on it.

Digital can play a significant role in facilitating and accomplishing the utilitarian factors affecting shopping experience like searching products, finding information, comparing products and checkout. Omni-channel retail strategy has been seen as a key competitive advantage in the retail industry in the past five years. Omni-channel retail strategy allows the brand to facilitate customers across multi channels through click stores and brick stores. Marta (2014) researched about how customers use the multi-channel for fashion shopping and it was found that customers use the e-commerce for searching 
information, comparing prices and, look for inspirations in the social media before shopping in-store and before customers place orders in e-commerce stores, they prefer to go to store to see and try the product. This raises questions what some brands are doing today in-stores by installing digital screens offering these services like, searching products, finding product information, connecting to social media etc., again in the brick stores. To understand this, the digital strategy of the Nike and Amazon brands in one of their retail stores are analyzed and both the cases are studied in detail correlating the findings from the research of field work and the data collected from customers.

\subsection{Nike case}

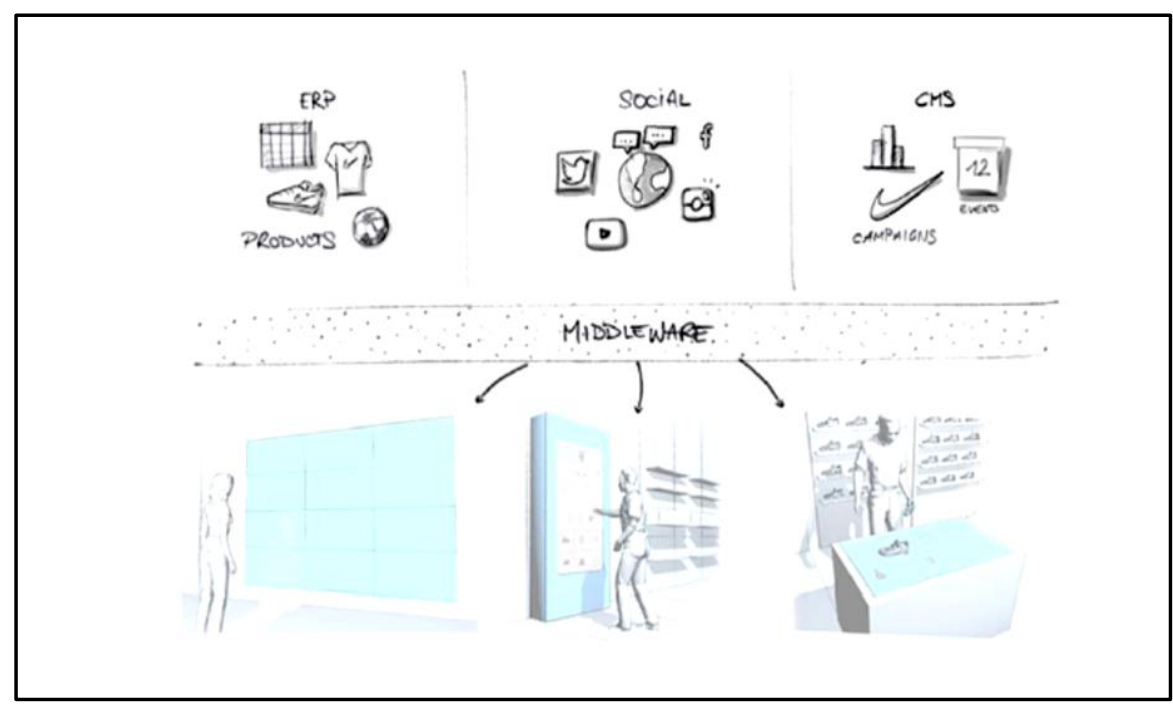

Figure 4: Nike digital experience architecture

Source: http://demodern.com/projects/nike-digital-retail-experience

To analyze what is being followed in different brand stores a case study about a Nike store in Berlin from its technology partner is presented below. Here Nike created a 'digital' retail experience which combines retail store, e-commerce and mobile customer journey. The figure above shows how the omni-channel retail strategy was conceptualized to create a connected store. It has these features:

A multi-touch, multi-user wall displaying products and social media campaigns is set up and the customers can take a selfie and share it on social media. It is perceived that this would increase customer engagement. A digital retail kiosk with a 65" touch display where Nike Football fans can find, customize and order their favourite Nike team products. It is perceived to manage the stock effectively even in a small retail space and make use of the available retail space effectively. A multitouch screen which facilitates comparing the different features of Nike products along with the availability of size, colour etc., from their ERP system. Nike store replicated the features of ecommerce store in the brick store with the objective of enhancing brand experience.

"Three custom built multi-user, multi-touch terminals expanded the brand experience with product information and online purchasing options" quoted by the technology partners who implemented this though there is no evidence given. Analyzing some sample comments in Google review show that better shopping experience was mainly due to the service level of the staff, product variety and the football club where Nike communicate the brand identity by telling relevant stories attracting football fans. As there are no comments about how the customers feel or excited by its digital experience or how useful it was during their shopping journey, it confirms what was studied in the research that digital cannot enhance the brand experience when it is not relevant to the brand or the product. 


\subsection{Amazon Go case}

Amazon has recently opened its first checkout free store in Dec 2015 in Seattle called Amazon Go which is now in beta version and available only to Amazon employees and is planned to be available to public soon. "We created the world's most advanced shopping technology so you never have to wait in line. With our Just Walk Out Shopping experience, simply use the Amazon Go app to enter the store, take the products you want, and go! No lines, no checkout" as quoted by Amazon. Customers can leave the store after picking their products and customer's online Amazon account will be charged and customers will receive the receipt. "I think it's definitely going to make other retailers stand up and take notice," said Patricia Orsini, an analyst at eMarketer. "It's addressing a lot of the pain points that people have in terms of shopping-the amount of time spent and standing in line and that sort of thing" (CNBC, 2016).

The Google ratings of this store which is opened only to the employees seemed to have been received well by the customers who used it and the zero waiting for checkout is the main factor leading to this rating though there is a limitation that it is not open to public.

\subsection{Case analysis}

The above two cases where digital in-store experience is incorporated has one difference: In Nike's case the objective was to enhance the brand experience and in Amazon Go's case the objective is to reduce the checkout time. Based on the literature reviewed and from the field work and the collected data, Amazon Go has used digital in the right place than Nike. Though the comments for Amazon cannot be used as a proof for the success of such concept as those are only from their employees, it correlates with the study done for this research and checkout waiting time is one of the major issues to be resolved in grocery shopping in super market. Like this, if the utilitarian values of the shopping are fulfilled either with the assistance of sales personnel or with an easy-to-use digital platform, it will enhance the shopping experience. In Nike the customers could have used the e-commerce and the online social media channels to get the information or services provided by the three interactive devices installed in-store. Investing in digital where the utilitarian factors can be fulfilled and facilitating the customers in their shopping journey seemed to create more impact.

\section{Framework for a brick store shopping experience}

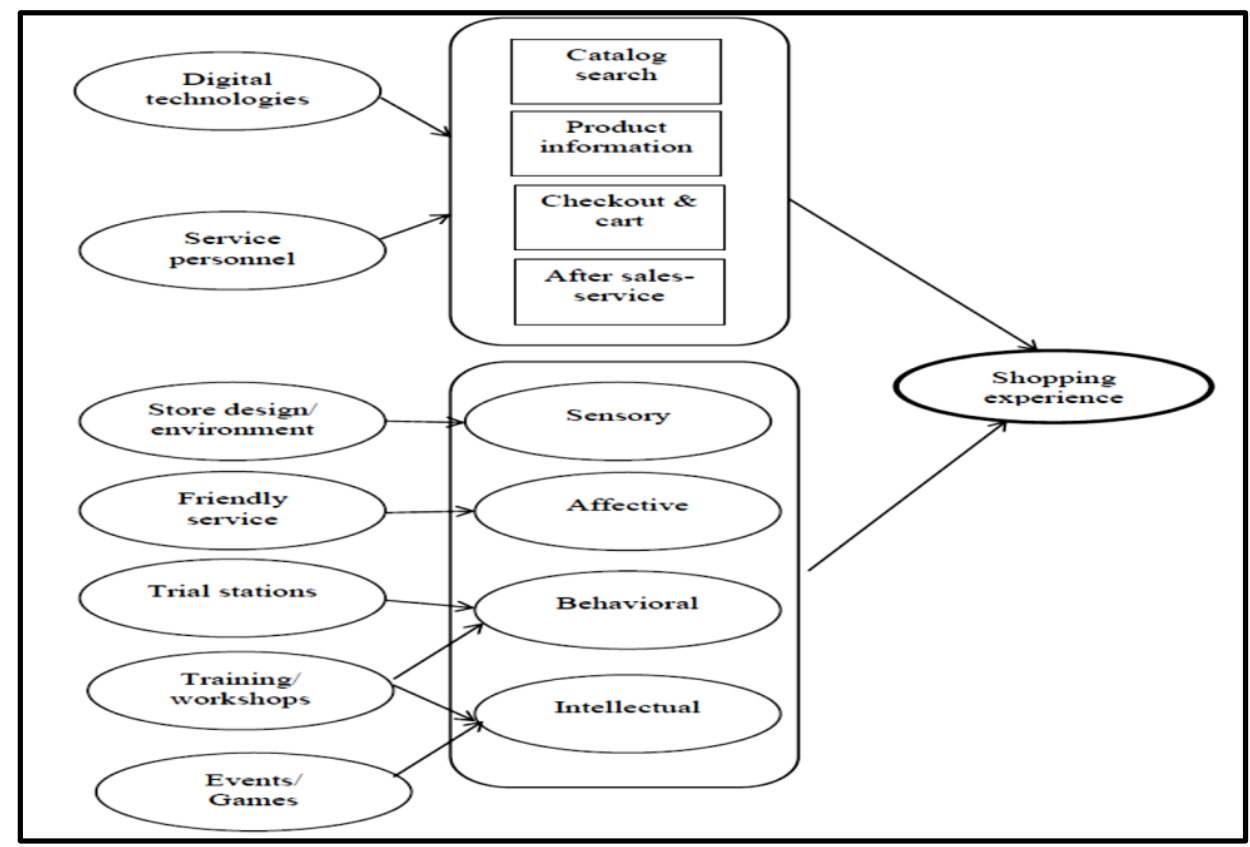

Figure 5: Framework for a brick store shopping experience 
Based on the field work, data collected and the literature reviewed, the framework in the figure above is created which explains the factors affecting the whole shopping experience and where digital can create positive impact. The stages of the shopping journey should be facilitated either by the digital technologies and or by service personnel for customers to attain the utilitarian values of shopping. Different dimensions of brand experience proposed by (Brakus et al., 2009) can be produced in brick stores. The figure depicts how different concepts affect the different dimensions of the brand experience. The concepts incorporated by social media such as community management, by posting and sharing the ideas, creating relationship, conducting games, etc., can be implemented physically in retail stores by organizing events, training, etc., to enable communication among the customers. The blogging concept can be implemented in retail stores where the retail brands can communicate about their brand by telling real stories in the stores. By enabling communication among the customers, a brand can create a unique experience and allow for the co-creation of experience that will engage customers and turn them as brand advocates and this will create positive affective, intellectual \& behavioral experiences. Based on the strategy of the business, it should be decided if only utilitarian factors need to be satisfied or hedonic factors should also be implemented as this is based on the strategic position of the company whether it is low cost or premium. It is also important that all the hedonic concepts implemented in the store should be related to the brand and should tell the relevant stories.

\subsection{Managerial implications and contributions of the research}

This research gives new insights to the retailers about their digital strategy in brick stores. It also highlights what a good shopping experience is from customers' perceptions and theoretical frameworks. When customers come to stores, the physical touch \& feel and the hedonic factors play an important role so customers expect to be received and offered information and assistance from the sales person than from the digital screens. Rather than creating a digital social media wall or play stations in the stores, creating a social environment will create a better impact on the shopping experience. The framework from the previous section will help the retailers to analyze where they are and what new steps can be taken to create a wholesome shopping experience to customers.

\subsection{Limitations and future directions}

This research study has the limitation on the qualitative data as it doesn't represent the behaviors of different customer groups as it requires large amount of data. Also the experimental study to examine the impact of digital on brand experience is limited to the perception and imagination of respondents. Though in-general with observation and casual chat with customers on how do they feel about the digital in brick stores, it is found that customers do not get excited about the digital technologies in brick stores. Digital technology if not adding any utilitarian value to the shopping journey of a customer may get customer attention in the first visit when it is introduced, but it will remain unused in the future and cannot enhance the brand experience. The future research can continue to validate the hypothesis developed quantitatively with different segments of customers to have deeper understanding on the changes of impact.

\section{CONCLUSION}

With the evolution of the internet and the rapid growth of e-commerce sales, there is a growing pressure for retail stores brands to maintain their market share of the total retail sales in the long-term. Brick stores retailers must put in place the right strategy to bring those fast moving online customers to the brick stores and to retain the existing customers who prefer to shop in the brick stores. There is also a another contradicting trend that online brands are opening the brick stores as it is perceived and proved as the best channel to interact directly with the customers and that would create better brand experience as the customer's involvement is higher.

Several researches in marketing and consumer psychology prove that there are multiple dimensions of customer experience. The field work and the data collected prove that customers' expectations are basic and if those basic utilitarian factors are satisfied across all the customer touch points in the 
shopping experience, that shopping experience is perceived as the best. Digital can create positive impact on shopping experience only when it is used to create utilitarian values rather than hedonic values. To make the shopping experience more memorable, touching customers' heart is more important than installing touch screens in the stores i.e. creating memorable experience affecting different dimensions of the brand experience namely sensory, affective, behavioral and intellectual can create a wholesome shopping experience. Customers prefer to be served by service personnel than digital devices and only in the cases where the waiting time is more, customers prefer digital services. The more the utilitarian and hedonic values are given by a retailer, the more that shopping experience would be perceived as the best. Rather than following a digital paradigm, it is time for the retailers to take a pause and think how to differentiate themselves considering the customers' expectations to create a better shopping experience challenging e-commerce.

\footnotetext{
Funding: This study received no specific financial support.

Competing Interests: The authors declare that they have no competing interest.

Contributors/Acknowledgement: All authors participated equally in designing and estimation of current research.

Views and opinions expressed in this study are the views and opinions of the authors, Asian Journal of Empirical Research shall not be responsible or answerable for any loss, damage or liability etc. caused in relation to/arising out of the use of the content.
}

\section{References}

Aguinis, H., \& Bradley, K. J. (2014). Best practice recommendations for designing and implementing experimental vignette methodology studies. Organizational Research Methods, 17(4), 351371. view at Google scholar / view at publisher

Babin, B. J., Darden, W. R., \& Griffin, M. (1994). Work and/or fun: measuring hedonic and utilitarian shopping value. Journal of Consumer Research, 20(4), 644-656. view at Google scholar / view at publisher

Borghini, S., Diamond, N., Kozinets, R. V., McGrath, M. A., Muñiz, A. M., \& Sherry, J. F. (2009). Why are themed brandstores so powerful? Retail brand ideology at American Girl Place. Journal of Retailing, 85(3), 363-375. view at Google scholar / view at publisher

Brakus, J. J., Schmitt, B. H., \& Zarantonello, L. (2009). Brand experience: what is it? How is it measured? Does it affect loyalty?. Journal of marketing, 73(3), 52-68. view at Google scholar I view at publisher

Bullard, B. (2017). In-Store experience. Style and Statistics: The art of retail analytics, 119-130. view at Google scholar / view at publisher

Charmaz, K. (1995). Grounded theory. Rethinking Methods in Psychology, 24, 27-49. view at Google scholar

Choi, Y. G., Choi, Y. G., Ok, C. M., Ok, C. M., Hyun, S. S., \& Hyun, S. S. (2017). Relationships between brand experiences, personality traits, prestige, relationship quality, and loyalty: An empirical analysis of coffeehouse brands. International Journal of Contemporary Hospitality Management, 29(4), 1185-1202. view at Google scholar / view at publisher

CNBC (2016). Amazon's grab-and-go stores to pressure grocers to step-up 'smart store' efforts. http://www.cnbc.com/2016/12/09/amazons-grab-and-go-stores-to-pressure-grocers-to-stepup-smart-store-efforts.html.

Dolbec, P. Y., \& Chebat, J. C. (2013). The impact of a flagship vs. a brand store on brand attitude, brand attachment and brand equity. Journal of Retailing, 89(4), 460-466. view at Google scholar / view at publisher

eMarketer. (2016). Worldwide retail ecommerce sales will reach $\$ 1.915$ trillion this year. Retrieved from https://www.emarketer.com/Article/Worldwide-Retail-Ecommerce-Sales-Will-Reach1915-Trillion-This-Year/1014369.

Goyal, L. (2017). Leading digital strategy: driving business growth through effective Ecommerce. Vikalpa, 42(2), 128-130. view at Google scholar / view at publisher 
Grewal, D., Levy, M., \& Kumar, V. (2009). Customer experience management in retailing: an organizing framework. Journal of retailing, 85(1), 1-14. view at Google scholar / view at publisher

Grewal, D., Roggeveen, A. L., Runyan, R. C., Nordfält, J., \& Vazquez Lira, M. E. (2017). Retailing in today's world: multiple channels and other strategic decisions affecting firm performance. Journal of Retailing and Consumer Services, 34, 261-263. view at Google scholar I view at publisher

Hagberg, J., Sundstrom, M., \& Egels-Zandén, N. (2016). The digitalization of retailing: an exploratory framework. International Journal of Retail \& Distribution Management, 44(7), 694-712. view at Google scholar / view at publisher

Johnson, J. S., \& Sohi, R. S. (2016). Understanding and resolving major contractual breaches in buyerseller relationships: a grounded theory approach. Journal of the Academy of Marketing Science, 44(2), 185-205. view at Google scholar / view at publisher

Kent, A., Dennis, C., Cano, M. B., Helberger, E., \& Brakus, J. (2018). Branding, marketing, and design: experiential in-store digital environments. In Fashion and Textiles: Breakthroughs in Research and Practice (pp. 275-298). IGI Global. view at Google scholar / view at publisher

Marta, B. (2014). Fashion shopping in multichannel retail: the role of technology in enhancing the customer experience. International Journal of Electronic Commerce, 18(4), 97-116. view at Google scholar / view at publisher

Ozkara, B. Y., Ozmen, M., \& Kim, J. W. (2017). Examining the effect of flow experience on online purchase: A novel approach to the flow theory based on hedonic and utilitarian value. Journal of Retailing and Consumer Services, 37, 119-131. view at Google scholar / view at publisher

Ozturk, A. B., Nusair, K., Okumus, F., \& Hua, N. (2016). The role of utilitarian and hedonic values on users' continued usage intention in a mobile hotel booking environment. International Journal of Hospitality Management, 57, 106-115. view at Google scholar / view at publisher

Parise, S., Guinan, P. J., \& Kafka, R. (2016). Solving the crisis of immediacy: How digital technology can transform the customer experience. Business Horizons, 59(4), 411-420. view at Google scholar / view at publisher

Puccinelli, N. M., Goodstein, R. C., Grewal, D., Price, R., Raghubir, P., \& Stewart, D. (2009). Customer experience management in retailing: understanding the buying process. Journal of Retailing, 85(1), 15-30. view at Google scholar / view at publisher

Reydet, S., \& Carsana, L. (2017). The effect of digital design in retail banking on customers' commitment and loyalty: The mediating role of positive affect. Journal of Retailing and Consumer Services, 37, 132-138. view at Google scholar / view at publisher

Saari, U. A., \& Mäkinen, S. J. (2017). Measuring brand experiences cross-nationally. Journal of Brand Management, 24(1), 86-104. view at Google scholar / view at publisher

Schmitt, B. (1999). Experiential marketing. Journal of Marketing Management, 15(1-3), 53-67. view at Google scholar / view at publisher

Schmitt, B. (2011). Experience marketing: concepts, frameworks and consumer insights. Foundations and Trends® in Marketing, 5(2), 55-112. view at Google scholar / view at publisher

Shetty, A. D. (2017). E-Commerce Industry Significant Factor for the Growth of Indian Economy. Asian Journal of Research in Social Sciences and Humanities, 7(4), 177-183. view at Google scholar / view at publisher

Sinha, P. K., \& Uniyal, D. P. (2005). Using observational research for behavioural segmentation of shoppers. Journal of Retailing and Consumer Services, 12(1), 35-48. view at Google scholar / view at publisher

Terblanche, N. S. (2018). Revisiting the supermarket in-store customer shopping experience. Journal of Retailing and Consumer Services, 40, 48-59. view at Google scholar / view at publisher

Verhoef, P. C., Lemon, K. N., Parasuraman, A., Roggeveen, A., Tsiros, M., \& Schlesinger, L. A. (2009). Customer experience creation: Determinants, dynamics and management strategies. Journal of retailing, 85(1), 31-41. view at Google scholar / view at publisher

Wang, W. T., Wang, Y. S., \& Liu, E. R. (2016). The stickiness intention of group-buying websites: The integration of the commitment-trust theory and e-commerce success model. Information \& Management, 53(5), 625-642. view at Google scholar / view at publisher 
Wimmer, K., Stiles, J., \& Abrams, B. (2001). The observational research handbook: understanding how consumers live with your products. Journal of Advertising Research, 41(1), 91-91. view at Google scholar

\section{Appendices}

\section{Annex 1}

\section{Observational study}

The stores are categories as "Digital store" below when it has one or two digital components and is promoted by that brand or bloggers as re-defining the customer experience through in-store digital experience.

\section{Observation field notes from store visits}

The field notes used for analysis of this research study is given below:

\section{Sephora Flash, 66 Rue de Rivoli, Paris (Digital-store)}

This store has smaller retail space than usual Sephora stores and best-selling products were found in the stores. There were less customers but the space is almost packed. The sales personnel were offering assistance to try the products as well as on how to use the digital shopping cart. It has the Click \& Collect feature and through digital basket -which is a digital card which has to be used when placing orders in a screen. Customers can place order for products not in-stock in that store but available in the other stores in Paris and delivered in 1 to 2 days. Customers can pay for the physical as well as virtual products added to that digital card together in the cash counter. In around 25 mins of observation, one girl used that digital shopping cart. When asked the store manager about how useful the digital shopping cart is, he said it is useful and many customers are using it. There is a big screen which allows user to take selfie and no user used it during the observation time and when the author tried to use it, after taking a selfie, it asks for email address and it did not work after that. The cash counter is not so crowded; around 2 persons were in the queue. There is also a digital kiosk which allows the customers to collect free samples after payment and 3 customers were standing in the queue to collect it.

\section{Sephora, 75 Rue de Rivoli, Paris (Non-digital store)}

This store is relatively larger compared to Sephora Flash, it has more variety of products. There were some offers and it was crowded and customers were seemed to be more enthusiastic and trying the products. One sales person offered to help the friend of the author and when it was asked if any sales person can speak English, English speaking sales assistant was sent to help her. The sales assistant suggested a particular brand and the offers available for that brand. In the cash counter for checkout, there were 3 persons. When inquired the sales person about the other branches and if any digital store nearby, he guided in a friendly way with smiling face. Later when checked in the social media about the comments for the products purchased, there were no positive comments for that product and when she decided to return the products, she returned it in another branch near her home and the return process was smooth and it was accepted.

\section{Sephora, Av. des Champs-Élysées, Paris (Non-digital store)}

This store has relatively larger retail space than the Sephora flash, it has more variety of products and it is crowded. Customers were mostly trying the products by themselves and were seen more enthusiastic. There were few sales persons guiding the customers and few of them seemed to be free waiting to serve customers looking for assistance. They offer many services some are free like: Flash makeup -15 mins quick makeup, Color profile -to find the skin colour tone, Make-up class on the basis of appointment and some paid services like: Complete makeup, Look VIP etc., There are around 3 make-up stations providing facial makeup service, nail art service, etc., and those make-up stations are filled with customers. 


\section{Nike Paris, 65-67 Av. des Champs-Élysées, Paris (digital store)}

This store has 3 storeys of retail space and more variety of Nike brand products was found and all the floors were seemed to be busy with customers though not very crowded. There is a static digital screen which explains about different outsoles available for different floor types. There are other digital screens which show the shoes used by football stars \& its highlights. There are 6 computers which allow accessing the Nikeid website which allows the customers to customize and the shoes. No one was using those computers during a 20 mins observation. The sales assistants were taking payments from the place where customers were sitting and trying the shoes using the mobile payment devices. They were also providing these services: Trial run, Nike+Run club, Nike training club, Bra fillting service, Click \& Collect.

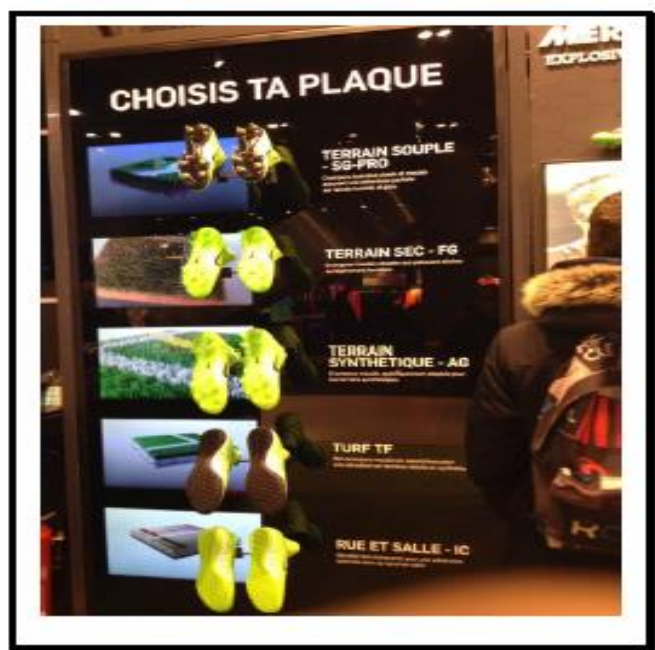

A

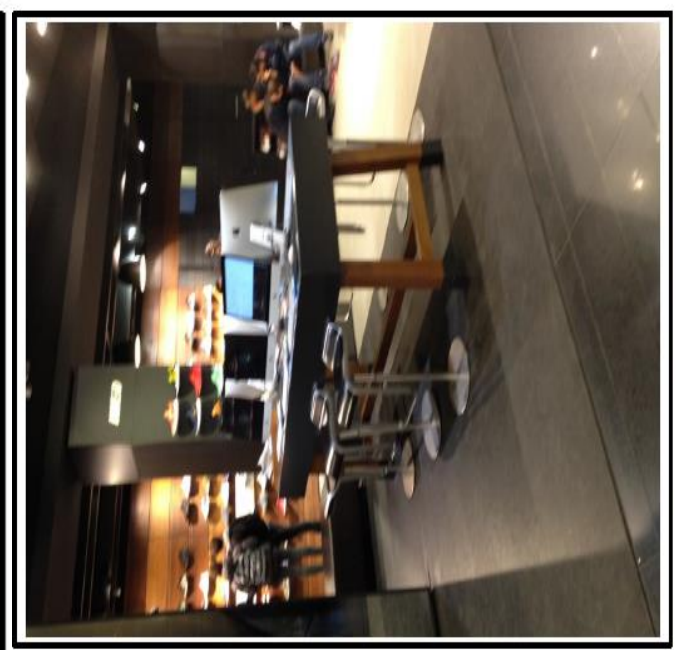

B

Figure 1(A): Nike store: Digital screen showing different outsoles available for different floor types Nike store: Computers enabling customize the shoes and order it

\section{Figure 1(B): Nike store: Computers enabling customize the shoes and order it}

\section{L'atelier Renault, 53 Avenue des Champs Élysées, Paris}

About this flaghsip store as quoted in the store's website: "This unique venue, a truly international flagship for the brand, gives you exclusive access to new products, first-time events and original experiences. Its mission: act as a hub to highlight and provide a platform for enthusiasts, new talent, makers, start-uppers and pioneers. This lively venue allows people every day to witness all the major changes happening around us, both today and in the future, with its specially-designed event programme. Renault, the iconic French carmaker, pursues the ambition to make innovation accessible to all. L'Atelier Renault has therefore naturally emerged as the imperative venue for French innovation to be showcased. Open to all visitors for a workshop, a gig, a gourmet treat or a digital experience, L'Atelier Renault aims to share its passion for life, demonstrated by the Renault automobile range, day after day. So whether you're more interested in technology, design, good food or music, L'Atelier Renault invites you to share your passion at 53 Champs-Elysées." Along with the information about the new models, information about the brand, it also has a selection of Renault souvenirs and merchandising: toys, miniatures, stationary \& the exclusive goods L'Atelier Renault. It has some fun elements quoted as "Sing, Play, Create" which allows: Singing in the Car, Jump for Twizy, Kids' CarToon and visitors especially those who come with kids use the "Jump for Twizy" which has a digital screen which instructs visitors to jump to charge the Twizy and when one of the players win, it shows a gift -which is to see and forward the jumping video. It also has L'Atelier Renault Café and Resturant in the top floor and around 2 tables were filled with customers. 


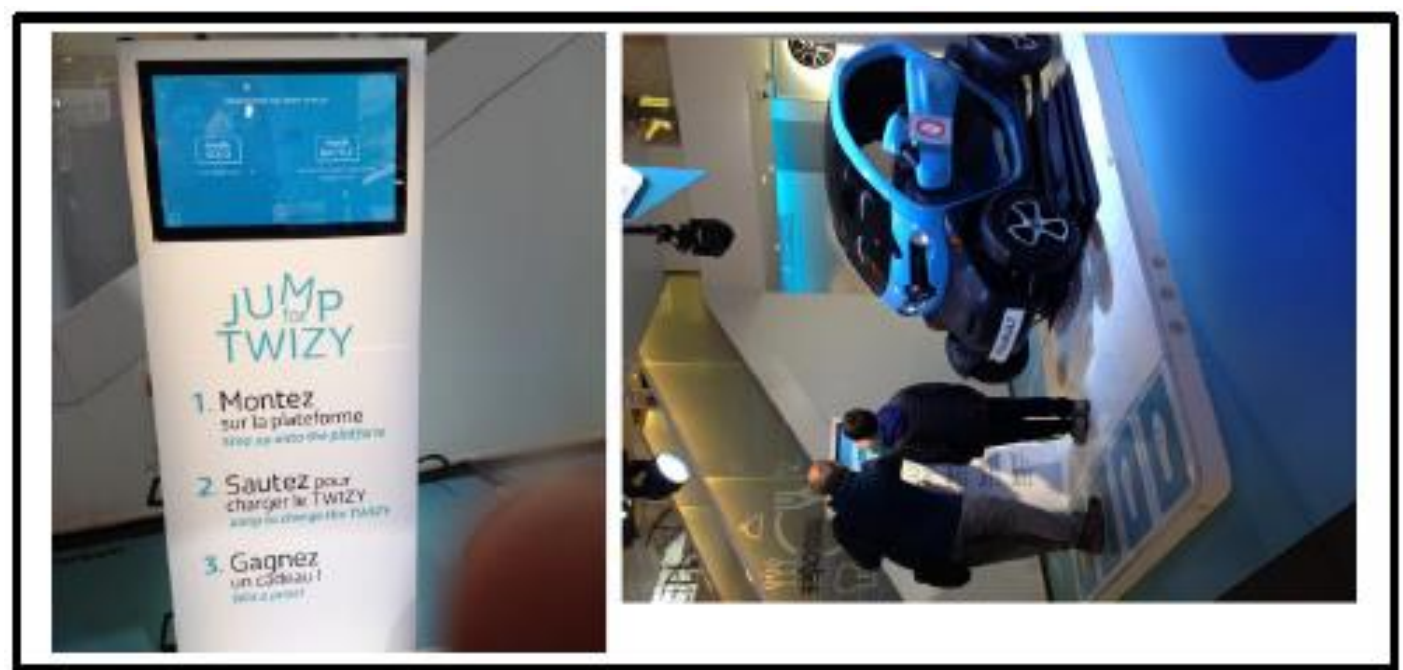

Figure 2: L'altier Renault: Digtal play station "Jump for Twizy"

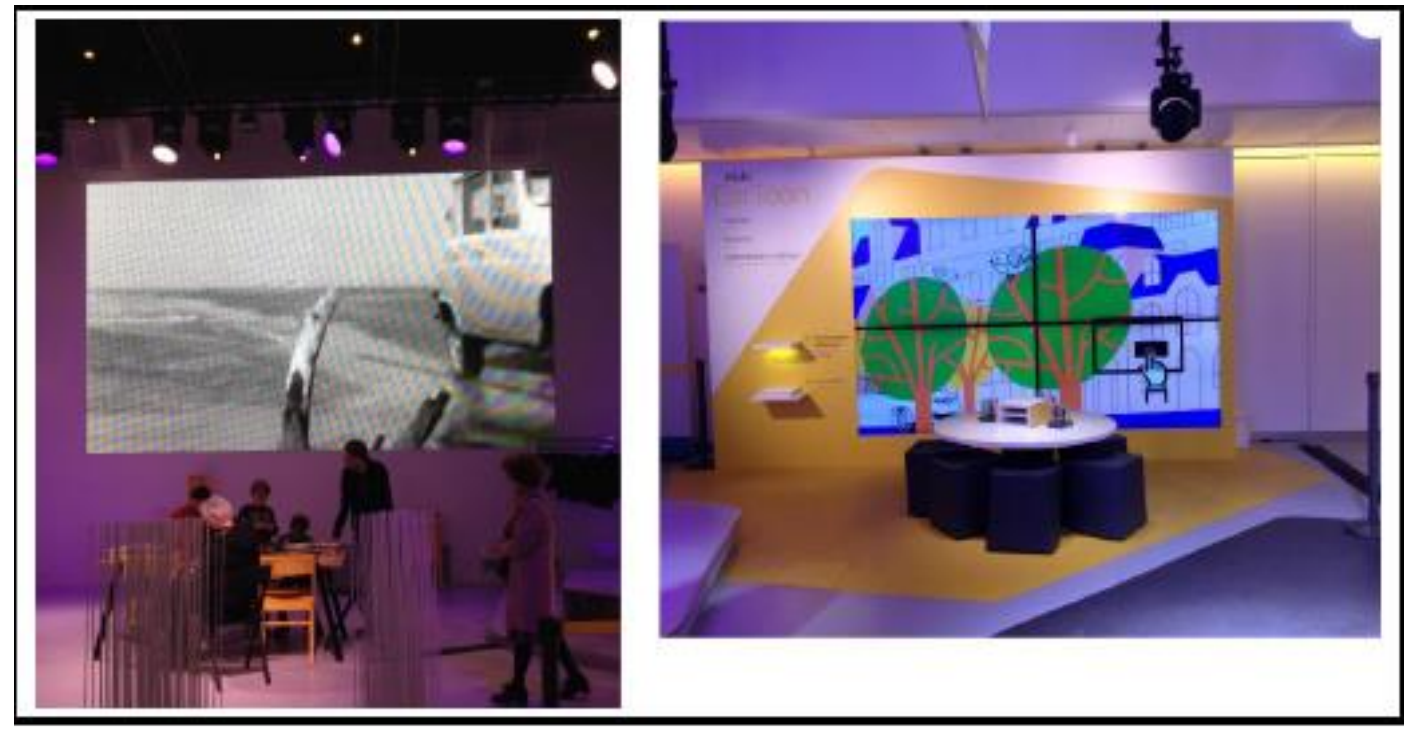

Figure 3: L'altier Renault: Physical kids play station with toy cars on left, Digital Kids' cartoon on right 


\section{Annex 2}

Study 3: Shopping experience scale

Table 1: Demographic profile

\begin{tabular}{clcccl}
\hline S. No & Store name & Your age & Sex & Working? & Residing country \\
\hline 1 & Mac & 32 & Female & yes & France \\
2 & Bose shop & 47 & Male & yes & France \\
3 & Nature et decouverte & 34 & Female & Yes & France \\
4 & Sephora & 28 & Female & Yes & France \\
5 & Currys PC world & 51 & Female & Yes & United Kingdom \\
6 & Tesco & 43 & Female & Yes & UK \\
7 & Matas & 36 & Female & Yes & Denmark \\
8 & Tesco & 40 & Female & No & UK \\
9 & Rituals & 24 & Female & Yes & France \\
10 & Next & 36 & Female & No & UK \\
11 & Bhv & 28 & Female & Yes & France \\
12 & NHS & 50 & Female & Yes & UK \\
13 & Leroy merlin & 42 & Male & Yes & France \\
14 & Asos & 23 & Female & Yes & France \\
15 & Carefour & 38 & Male & Yes & France \\
16 & Dantan & 32 & Male & Yes & France \\
17 & FNAC & 39 & Male & Yes & France \\
18 & Darty & 48 & Female & Yes & France \\
19 & Hamilton & 40 & Male & Yes & France \\
20 & Apple store & 43 & Male & Yes & France \\
21 & Saturn & 28 & Male & Yes & Germany \\
22 & Darty & 48 & Female & Yes & France \\
23 & Sainsbury & 54 & Male & No & England \\
24 & Morrisons & 70 & Female & No & England \\
\hline
\end{tabular}

\section{Utilitarian factors of shopping experience}

I can easily tınd my product (24 responses)

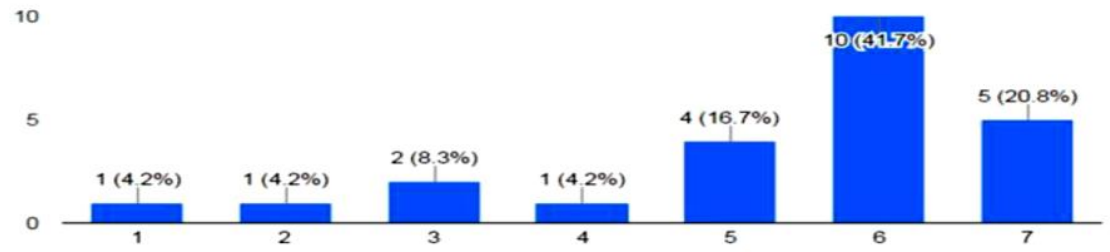

I can find required information about a product (24 responses)

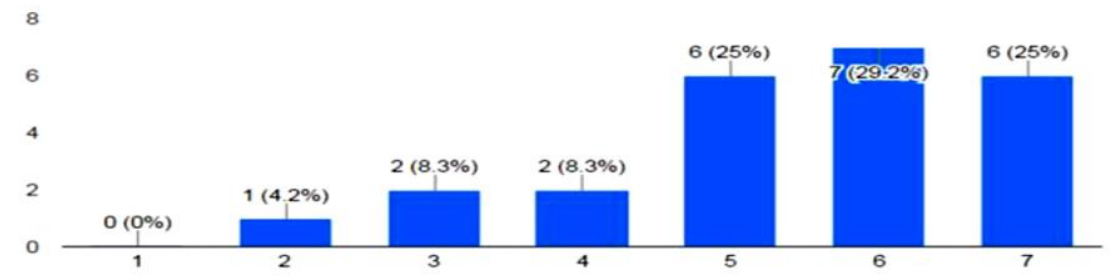


I can compare products easily before making the purchase (24 responses)

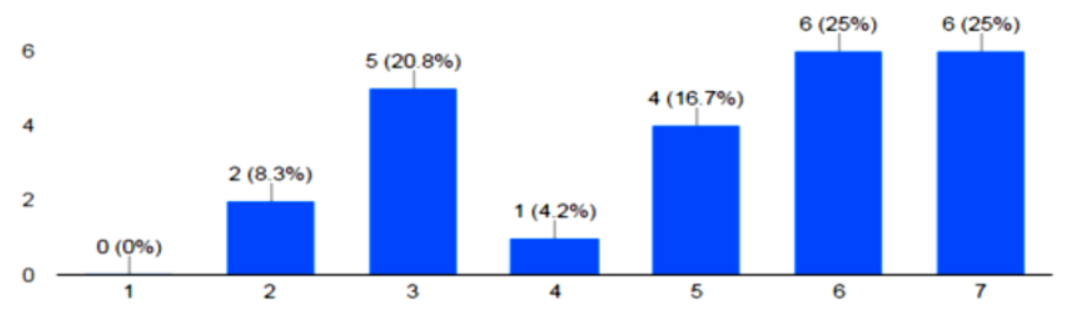

I don't have to wait more time to complete my order (24 responses)

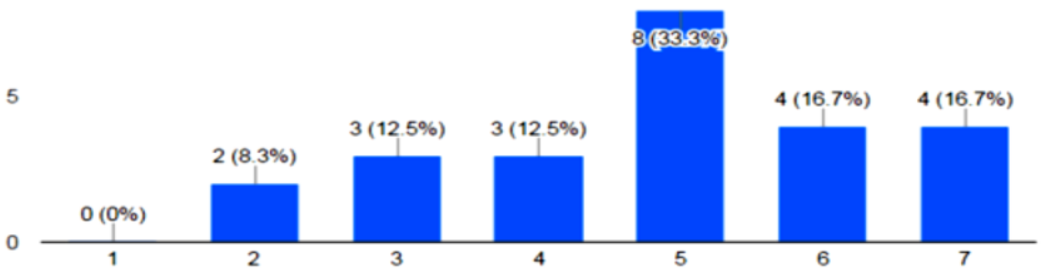

I can easily manage my returns (24 responses)

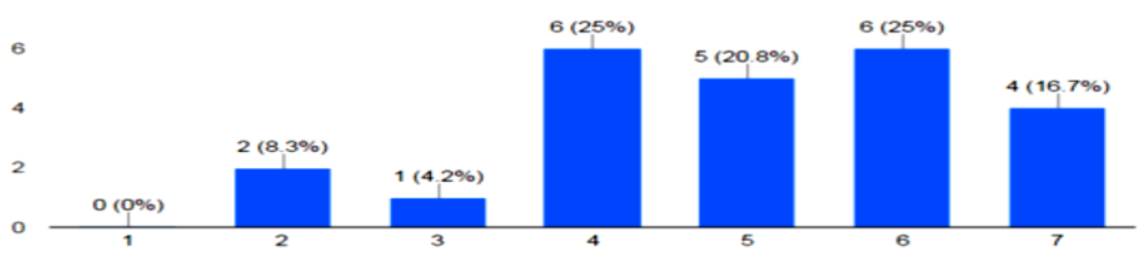

I get relevant tips before purchasing a product (24 responses)

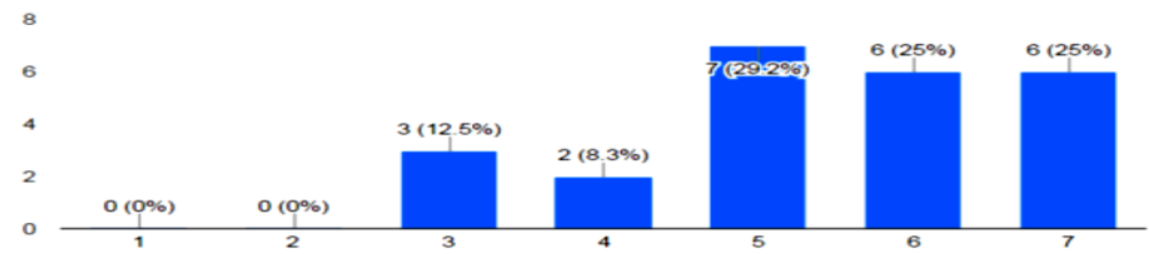

Figure 4: Utilitarian factors of shopping experience 


\section{Strength of brand experience dimensions}

This brand makes a strong impression on my visual sense or other senses (24 responses)

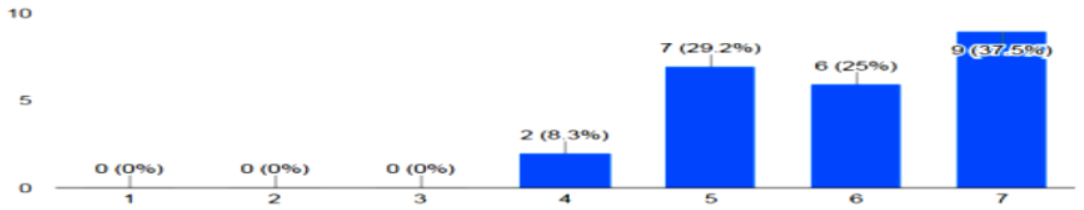

I find this brand interesting in a sensory way. (24 responses)

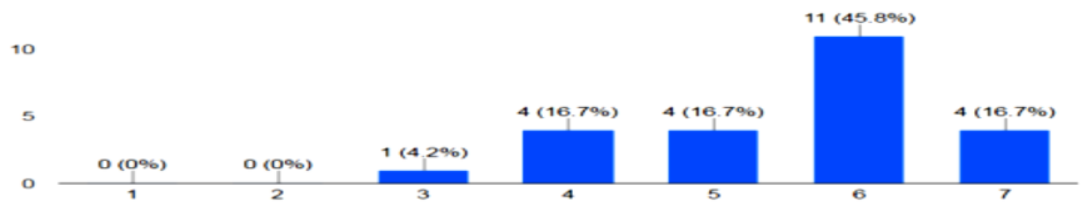

This brand does not appeal to mysenses (24 responses)

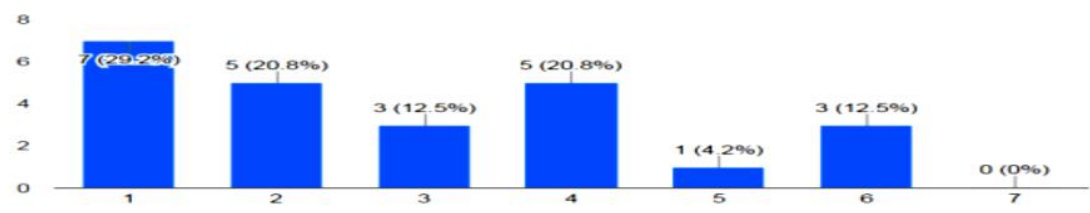

This brand induces feelings and sentiments. (24 responses)

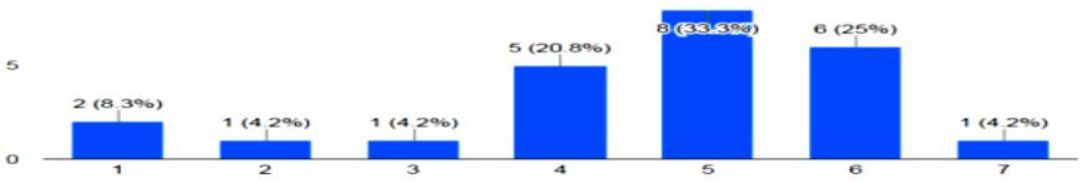

I do not have strong emotions for this brand. (24 responses)

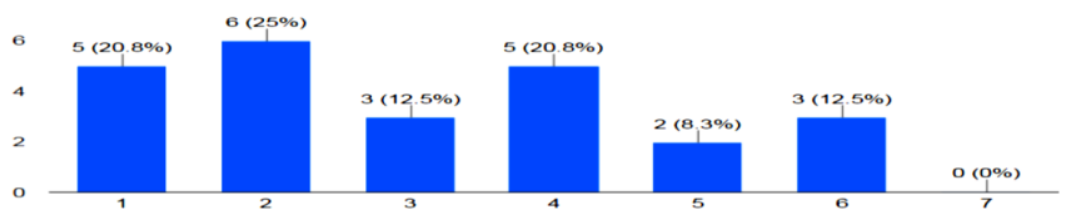

This brand is an emotional brand (24 responses)

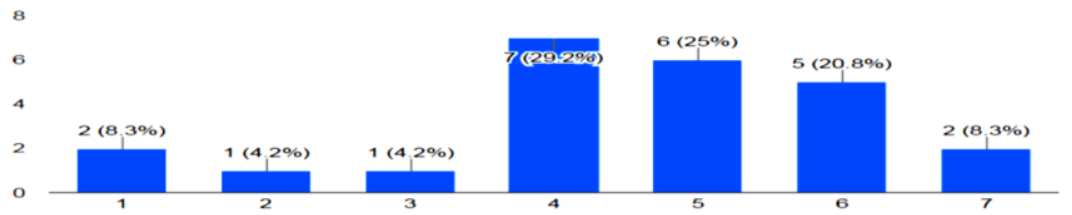


I engage in physical actions and behaviors when I use this brand. (24 responses)

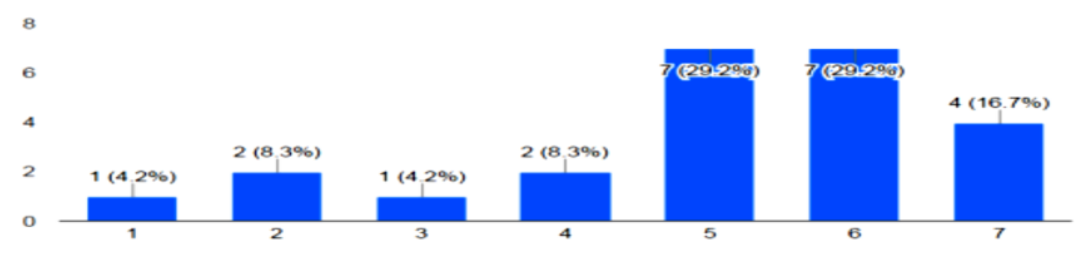

This brand results in bodily experiences. (24 responses)

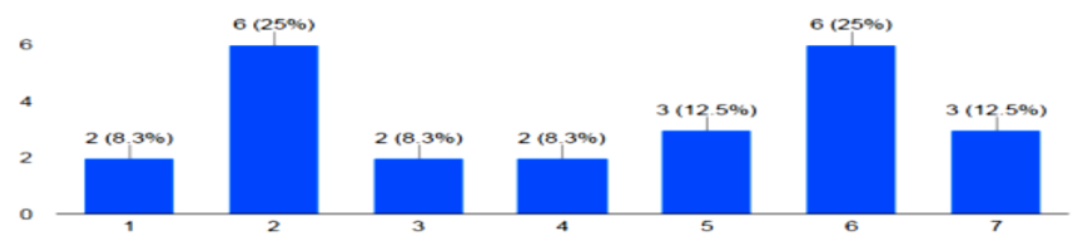

This brand is not action oriented. (24 responses)

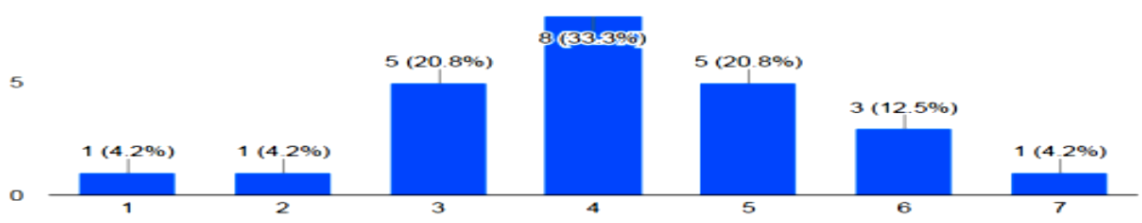

I engage in a lot of thinking when I encounter this brand. (24 responses)

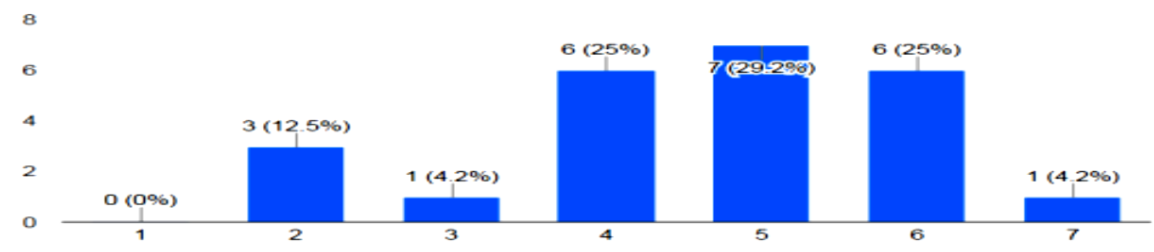

This brand does not make me think (24 responses)

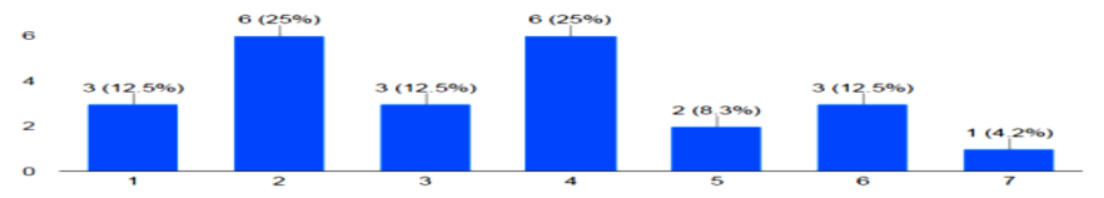

This brand stimulates mycuriosity and problem solving

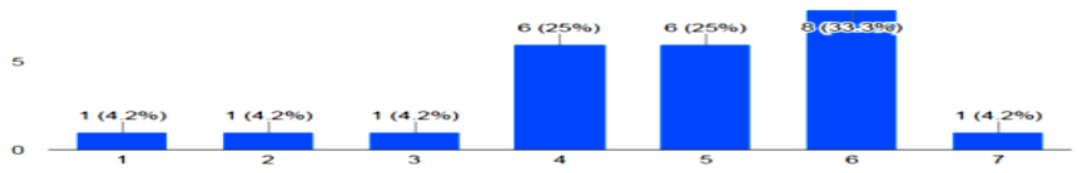

Figure 5: Strength of brand experience dimensions 


\section{Annex 3}

Study 04: Results of scenario based experiment

Table 2: Demographic profile

\begin{tabular}{ccccc}
\hline S. No & Age & Sex & Working? & Residing country \\
\hline 1 & 34 & Female & No & France \\
2 & 34 & Female & Yes & Denmark \\
3 & 32 & Female & No & United States \\
4 & 30 & Male & Yes & France \\
5 & 25 & Female & yes & Denmark \\
6 & 26 & Female & yes & Denmark \\
7 & 29 & Male & yes & Denmark \\
8 & 38 & Male & yes & Denmark \\
9 & 31 & Female & yes & United States \\
10 & 52 & Female & yes & UK \\
11 & 42 & Male & yes & France \\
12 & 23 & Female & yes & France \\
13 & 38 & Male & yes & France \\
14 & 34 & Female & yes & France \\
15 & 21 & Male & yes & France \\
16 & 29 & Female & No & France \\
17 & 29 & Male & Yes & France \\
18 & 27 & Female & No & France \\
19 & 65 & Male & Yes & France \\
20 & 37 & Male & Yes & UK \\
21 & 43 & Female & Yes & Germany \\
22 & 23 & Female & yes & Switzerland \\
\hline
\end{tabular}

Table 3: Scenario preference

\begin{tabular}{cccc}
\hline S. No & Non-Digital (Score) & Digital (Score) & You prefer which Scenario? \\
\hline 1 & 4.5 & 4.2 & Scenario 1 \\
2 & 6.8 & 6.9 & Scenario 2 \\
3 & 3.8 & 3.8 & \\
4 & 5.5 & 2.9 & Scenario 1 \\
5 & 4.6 & 3.9 & Scenario 1 \\
6 & 4.6 & 4.1 & Scenario 1 \\
7 & 1.8 & 1.2 & Scenario 1 \\
8 & 4.2 & 4.9 & Scenario 2 \\
9 & 3.8 & 3.3 & Scenario 1 \\
10 & 4.4 & 4.0 & Scenario 1 \\
11 & 6.0 & 2.8 & Scenario 1 \\
12 & 5.8 & 5.0 & Scenario 1 \\
13 & 4.2 & 6.9 & Scenario 2 \\
14 & 5.0 & 6.1 & Scenario 2 \\
15 & 4.1 & 4.0 & Scenario 1 \\
16 & 4.3 & 3.9 & Scenario 1 \\
17 & 3.9 & 2.3 & Scenario 1 \\
18 & 5.4 & 3.1 & Scenario 1 \\
19 & 4.8 & 4.8 & Scenario 2 \\
20 & 4.5 & 4.0 & Scenario 1 \\
21 & 3.6 & 3.8 & Scenario 2 \\
22 & 4.8 & 5.1 & Scenario 2 \\
\hline
\end{tabular}

